\title{
脳内侵入をきたし脳膿瘍を伴った鼻・副鼻腔乳頭腫の１例
}

内田 耕一・峯徹・竹中 信夫・井上 洋・行木 英生 ${ }^{*} \cdot$ 鈴木 慶二**

\section{Inverted Papilloma of the Nose and Paranasal Sinuses with Transdural Intracerebral Extension accompanied by Brain Abscess}

\author{
Case Report
}

\author{
Koichi Uchida, Tohru Mine, Nobuo Takenaka, Hiroshi Inoue, Hideo Nameki* \\ and Keiji SUZLKI**
}

Department of Neurasurgery, Ashikaga Red Cross Hospital, Ashikaga, Tochigi; *Department of Otolaryngology, Tochigi National Hospital, Utsunomiya; ${ }^{* *}$ Department of Pathology, College of Medical Care and Technology, Gunma University, Maebashi

\begin{abstract}
A 64-year-old male who had repeatedly undergone polypectomy for nasal polyps over a 20-year period was hospitalized with a "heavy feeling' in the head and disturbance of memory. Physical examination revealed the right nasal fossa to be almost completely blocked by a granular polyp. Neurological examination disclosed slightly impaired mental function, slight right exophthalmos, and bilateral papilledema. Skull X-rays revealed homogeneous clouding of the right nasal cavity and paranasal sinuses and an expansile lesion, resembling a mucocele, in the right frontal sinus. Computed tomography (GT) disclosed a soft-tissue mass in the right nasal cavity, paranasal sinuses, and orbit, with expansion of the right frontal sinus and destruction of the nasal septum, medial wall of the orbit, and roof of the frontal sinus. A patchy intracerebral mass with ring-like enhancement lay close to the expanded frontal sinus. Histological examination of the mass in the nose and paranasal sinuses showed typical inverted papilloma with a small malignant focus, and the diagnosis was squamous cell carcinoma. The intracerebral mass, which was also an inverted papilloma, was accompanied by a brain abscess and was not malignant. Intracranial extension is apparently a rare complication of inverted papilloma; only six such cases have been reported in the world literature. This appears to be the first reported case in which an inverted papilloma destroyed the dura mater and invaded the brain.
\end{abstract}

Key words: brain abscess, dura mater, inverted papilloma, nasal neoplasms, paranasal sinuses

\section{I はじめに}

鼻および副鼻腔乳頭腫は比較的京れな腫瘍であり，組織 学的には良性でありながら，骨破壊，再発，癌化方るい: 癌との共存が指摘され, histologically benign, clinically malignant と言われ，特に耳鼻科領域では注日されている
疾患のーのでかる。

今回我々は，前頭洞天葢安破壊し，さりに硬膜を貫いて 脳内に侵入，脳膿瘍を伴った鼻・副鼻腔乳頭腫の1例を経 験し太，鼻・副鼻腔乳頭腫の頭蓋内人の侵入は現在まで6 例の報告をみるのみであるが，ずべて骨破壊による頭蓋底 部への侵入であり，硬膜をも破壊し脳内に侵入した報告は 
ない,9,16)。我々の知る限り，transdural invasionによる脑

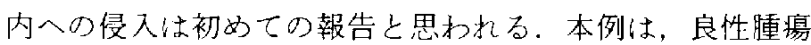
でありながらその病態は激烈で，骨执よび硬膜破壊により 脳内に侵入したものであり，非常に興味深い症例亡思斿 たので，文献的考察を加文報告する。

\section{II 症例}

<患者〉64才，男性

主訴：頭重感，物忘机

既往歴：最近20年間に10数回の鼻茸切除術学受けてい z.

家族歴：特記すべきことなし

現病歴：1985年 4 月初旬より軽度精神譏能低下が出現 し，動作緩慢上なった。またこの頃より頭重感が出現し た。他院にて CTが施行され，右前頭葉占挟性病变を指摘 されたため，5月15日光科紹介入院となった。このときま て明らかな髄膜炎症状を認めないが，しばしば微熱があっ たとい5.

入院時所見：神経学的心は軽度精神機能低下，軽度石眼 球突出からり，眼底仙両側 万っ血乳頭で石乳頙椂出血を認 めた，鼻鏡所見では，右鼻空に分葉状肉芽状 polyp が充満 していた，血液一般，生化学検査では特に異常を認めなか ったが，赤沈軽度㐫進，CRP $3+$ であった。

神経放射線学的所見：頭蓋単純撮影では，右鼻整および 副鼻腔は混濁し，正常の含気は劝られなかった，右前頭洞 は著明に拡大し， marginal scallopingは消失して平滑な鬥 形を呈していた，粘骨膜楾は一部小鮮明で眼窩上付側壁の 破壊がみられ，前頭润 mucocele 思わせる所見であのた

(Fig. 1).
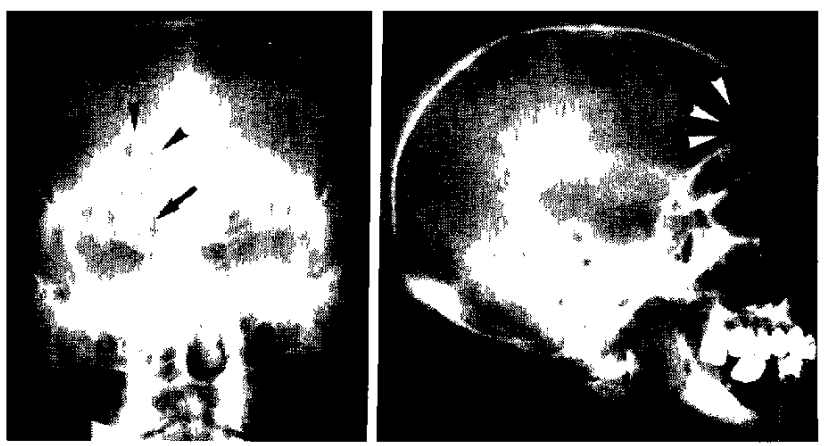

Fig. 1 Anteroposterior (left) and lateral (right) views of the skull reveal homogeneous clouding of the right nasal cavity and paranasal sinuses, and an expansile lesion in the right frontal sinus mimicking a mucocele (arrowheads). Bone destruction is seen at the medial wall of the right orbit (arrow).
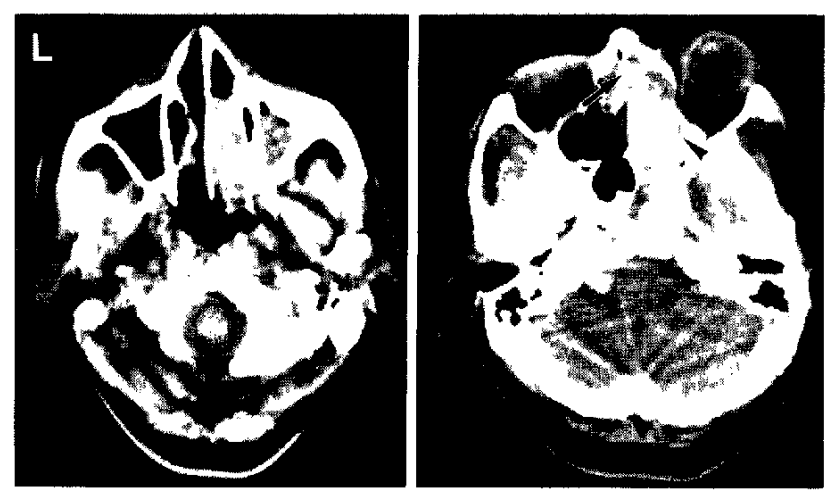

Fig. 2 Plain computed tomography (CT) scans at the level of the maxillary sinus (left) and orbit (right) disclose a softtissue mass in the right nasal cavity and maxillary and ethmoid sinuses, with destruction of the nasal septum (arrow) and medial wall of the right orbit (arrowhead).
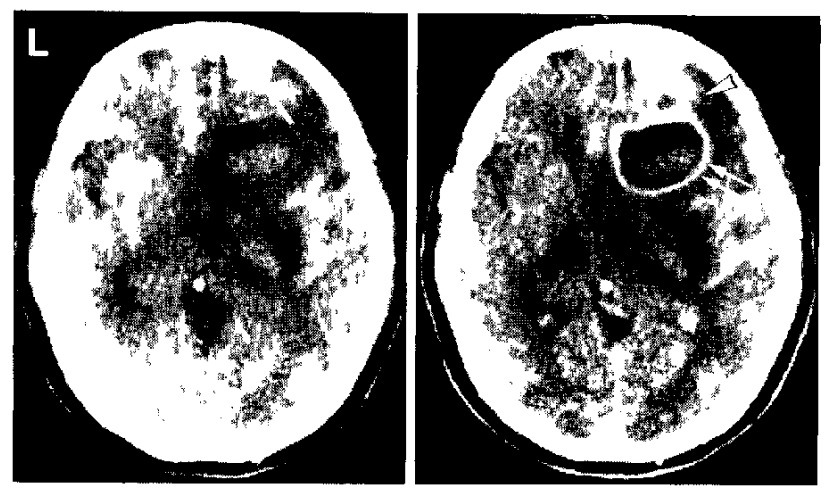

Fig. 3 Plain (left) and enhanced (right) CT scans reveal expansion of the right frontal sinus and destruction of its roof (arrow). A patchy, enhanced intracerebral mass (arrowhead) with adjacent ring-like enhancement (double arrow) lies close to the expanded frontal sinus.

上顎洞，鼻咽頭レベル，眼浻レベルの plain CTにて， 右鼻腔および副鼻腔に soft-tissue density mass が欢られ， 一部鼻中隔の破壞があり，対側への浸潤がみられた。 た，眼登内側壁が破壊され，睡瘍の眼窩内侵入と眼球突出 を認めた（Fig．2），頭部 CTでは，前頭洞は著明に拉大し ており天蓋に骨欠損圭認め，子の内部には soft-tissue density mass が充满し，前頭葉内には周围に著明な浮腫と正中 構造の偏位を伴ら等吸収から高吸収を示す mass を認めた。 Enhanced CTにて，前頭洞内 mass とそれに接した前頭葉 内 mass心壮不規則なマダラ状堌強效果が开られ，さらに そ机連続して ring状の增强像を認めた(Fig. 3)。李 。 coronal CT にて，前頭洞加ら脳内 mass の様子加さらに明 らかとなった，前頭洞部以外には頭蓋底部の骨破壊，腫瘍 


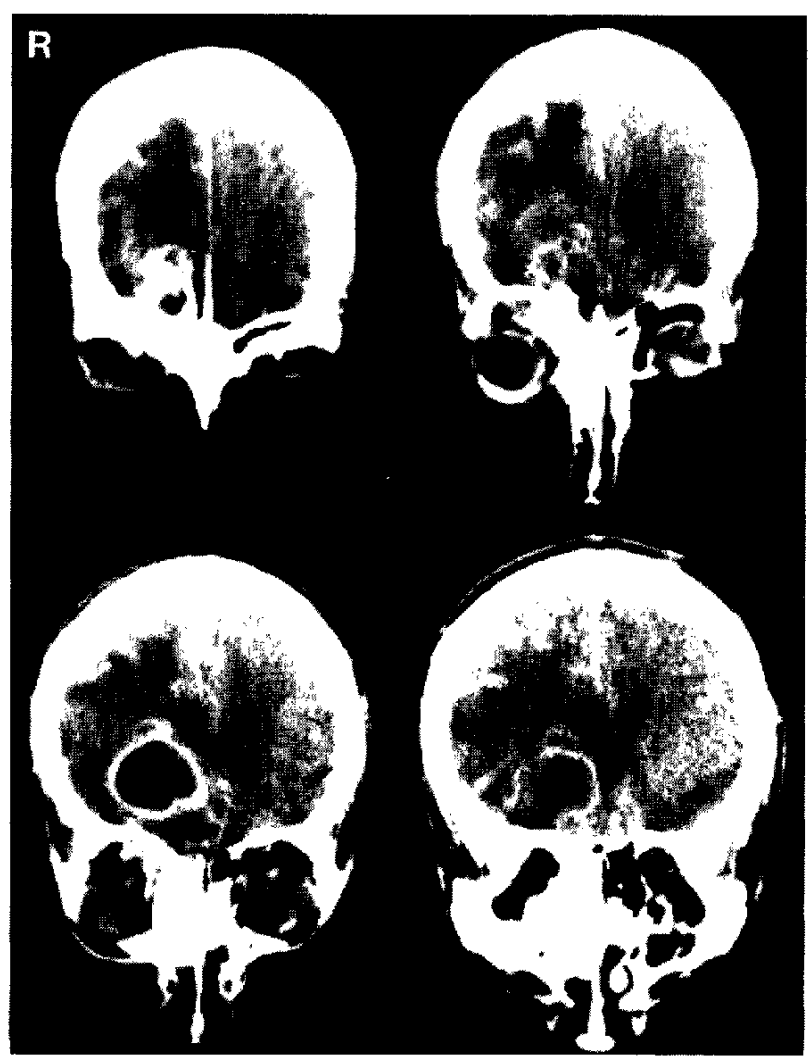

Fig. 4 Enhanced CT scan (coronal section) reveals a patchy, enhanced mass in the right nasal cavity, paranasal sinuses, orbit, and frontal area and an area of ring-like enhancement.

の頭蓋底浸潤など，特に異常を認めをがた（Fig. 4)。

手術所見：1985年 5 月 18 日，経鼻的に鼻・副鼻腔腫㣀摘

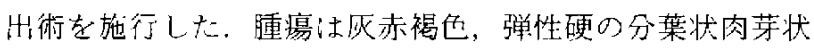
polypで，右鼻腔に允満し，きわめて易出血性であった。 鼻腔および篩骨洞队腫瘍之前頭洞内腫瘍の一部を摘出した が，上顎洞は開洞しなかった。

6 月 3 日, 脳腫瘍の疑いにて右前頭開頭に上る腫瘍摘比 を試双た。声硬膜内に入り，前頭洞骨欠損部の硬膜に弦 く癒着した赤褐色で弾性硬り腫瘍しこれに連続して脳内に 黄白色の㫗い被膜を有する腫瘍を認め，これを一塊として 摘出した（Fig，5)，硬膜に強く瘉着した腫瘍沈 cauliflower

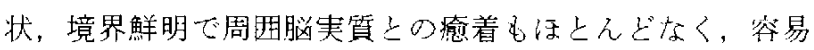
に剩離でさた。また、この腫瘍は前頭極動脈により栄養さ れていたここの腫瘍に連続した腫湯は境界不鮮明で，周囲 脳実質に強く癒着しており，穿刺心て乳白色の液体在得 た。さとに硬膜外に操作を進め，前頭洞骨久損部より前頭 洞㧍よび眼窩内腫瘍を piecemealに摘计した。睡瘍付着部 硬膜:土赤褐色に変色し肥厚していたか，肉眼的心は硬膜の

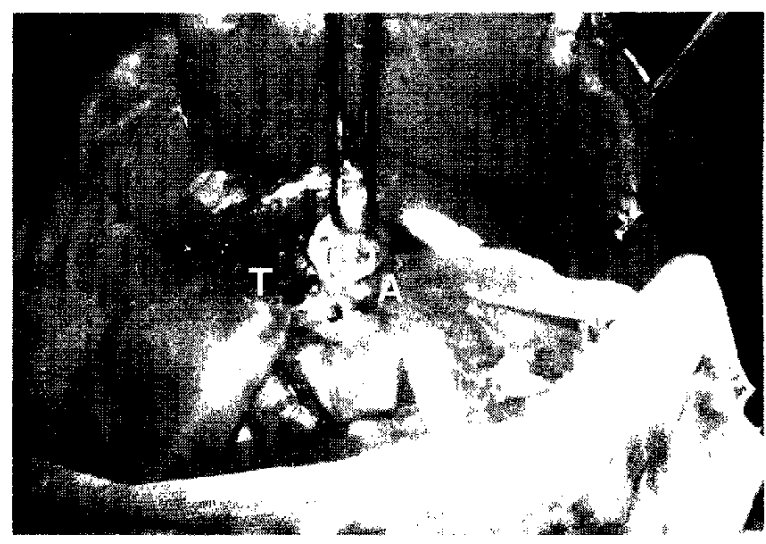

Fig. 5 Intraoperative photograph demonstrating a brownish, hard tumor ( $\mathrm{T}$ ) and a brain abscess (A) lying close to the dura mater at the frontal sinus.

断裂，欠損，腫湯の浸潤なとを認めず，これを切除した。 硬膜は watertightに閉鎖し，前頭洞骨欠損部はbone wax， oxycel, dibekacin sulfate (panimycin)を混台したものて pack L修復した。

病理組織学的所見：鼻・副鼻空腫瘍の病理組織をみる 之, 胚細胞, 線毛上皮, 扁平上皮加的成る典型的な inverted papilloma $の$ 像を呈 L，細胞に異型求よび多形や核 分裂像は子ら扟なかった(Fig. 6A)。その隣接組織には核 の大小不同があり，核分裂の多い扁平上皮癌の浸潤性発育

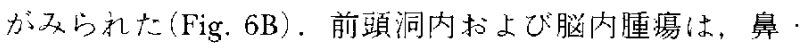
副鼻腔腫瘍上同様 inverted papilloma 0 像を呈したが，ど

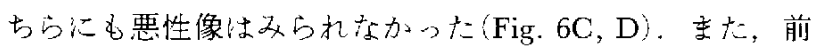
頚洞内乳頭腫の骨梁内侵入を認めた。脳内 inverted papilloma 亿連続した黄白色の㫗い被膜を有する腫癔は， 好中球浸潤を伴った炎症性肉芽で被膜が厚く，陳旧性脳膿 瘍の像女呈した（Fig. 6E). 腫瘍癒着部硬膜は大部分線維 化した肉芽組織から成り，正常の硬膜の構造は破壊され， 一部硬膜様組織の残存分みらられ（Fig. $6 \mathrm{~F})$.

以上より，鼻・副鼻腔 inverted papilloma が硬膜を破壞 して脳内へ侵入し脳膿瘍を伴ったものと診断した。

術後経過：術徭経過㳉良好で，精神機能は完全に回復 しなんら症状を残寸こ上なく退院したが，1985年12月末 頃より右前額部に発赤および腫脹か出現した。皮下および 硬膜外膿瘍の診断にて，1986年1月27月病巣を掻爬した。 感染のfocusは前頭洞胃欠損部修復に用いた bone wax と 考えられたためこれをす心て掻爬し，骨弁は肉眼的に感染 のないことを確認したらえで大腿外側部に埋没した，感染 が治るのを待って，2月21日前頍洞骨欠損部を修復し頙蓋

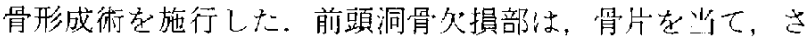



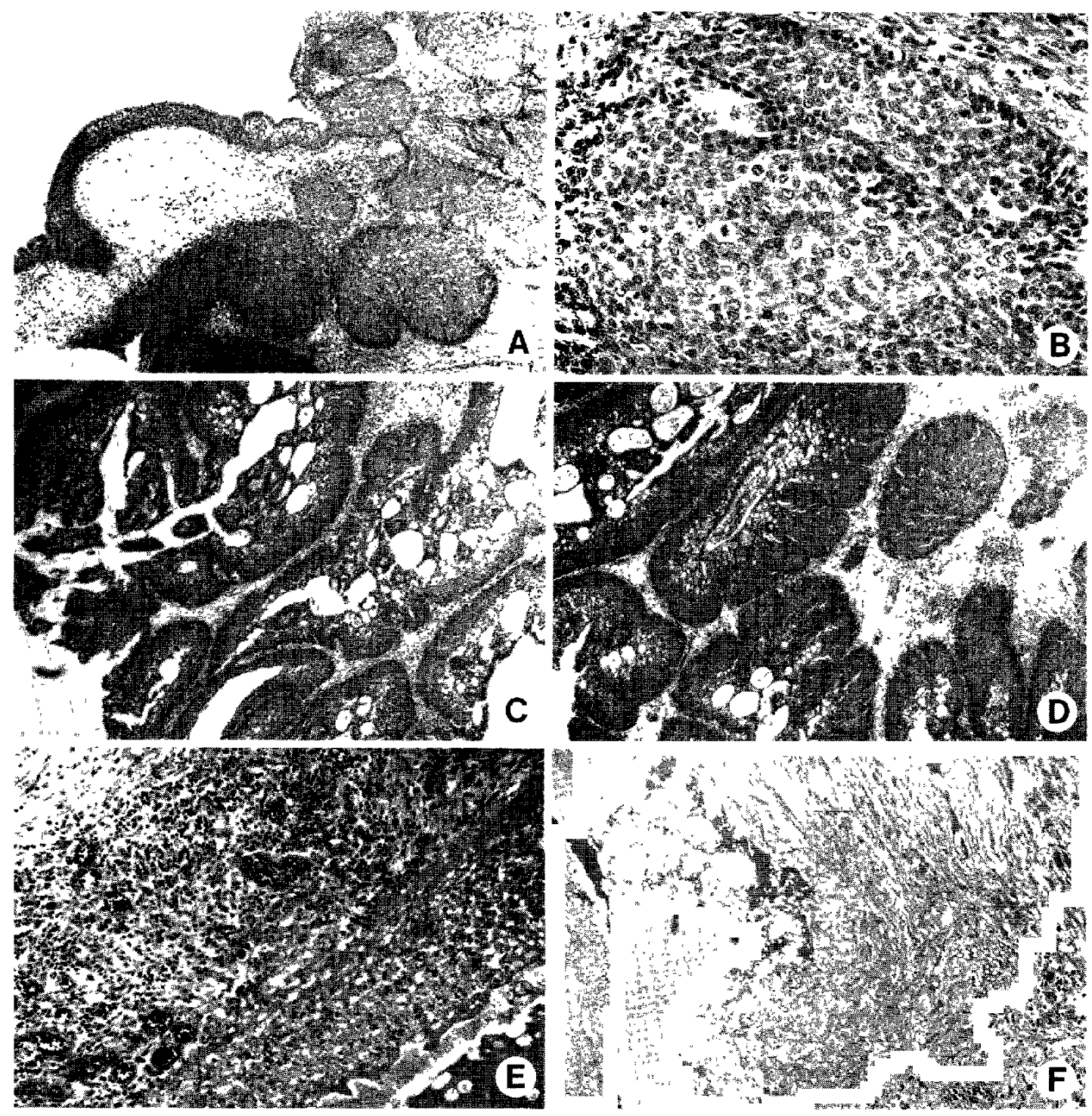

Fig 6 Histological appearance of the surgical specimens A. The mass from the nose and paranasal smuses shows a pattern typical of inverted papilloma Tumor cells extend into the underlying stroma without invading the basement membrane. HE stain, $\times 100$ $B$ : At the edge of the nasal tumor there is a small malignant focus, which was diagnosed as squamous cell carcinoma HE stain, $\times 400$. C. The mass in the frontal sinus was a papilloma with no malignant focus. HE stain, $\times 200 \quad$ D: The intracerebral mass in the right frontal lobe was also a benign papilloma HE stain, $\times 200 \quad$ E Brain abscess with granulation tissue HE stain, $\times 250$. F: The dura mater underlying the intracerebral papilloma and granulation tissue adjacent to the normal dural tissue HE stain, $\times 250$

らに大腿外側部より採取した筋膜にて pack した。また， 5 月 8 日 Denker 氏手術を施行し，右上顎洞に残存した腫 瘍を全摘した。

現在，再発の兆候子なく，元気に社会復㷌している。

$$
\text { III 考 察 }
$$

鼻・副鼻腔に発生する乳頭腫は1854年 Ward ${ }^{18)}$ が初めて
報告し，1855 年 Billroth ${ }^{1 /}$ が 2 例の鼻腔乳頭腫 Zotten Krebs として報告して以来，数多くの報告が尔る．本腫瘍 の病理組織学的検索は1883年. Hopman ${ }^{5 i}$ か hard papilloma と soft papillomaに分類したことに始去り，さらに腫痬の 構成細胞, 腫瘍細胞の増殖形態などより種々の病理組織 学的分類がなされてきだ. Inverted papillomaを最初に 記載したのは1938年 Ringertz'22であり，上皮組織が基底層 
に向かって樎入性に増殖することに注目し，inverting papilloma $と$ 命名した。

鼻・副鼻腔乳顽腫は全鼻および副鼻腔腫瘍の $4 \%$ にすぎ ず，白人化多く有色人種には少ない之される6)，その成因 については，慢性炎症刺激説，virus 感染説，糖原沈着説 など諸説があるが，いまだ確固たる定説はない2,81，好発 年齢は40～60才台で，男性比多い、15)，好発部位は鼻腔側壁 で，中鼻甲介や篩骨洞に多いと言われる2,13,17)が，その激 しい破壊性のため正確な好発部位に言及することは困難で ある。

本腫瘍の大きな特徵は，良性腫境でありながら骨破壊が 強く，再発を繰り返し，高頻度汇癌化曹るいは癌と共存夺 ることである．Skolnikらは，本腫瘍の50\%に骨破壊を伴

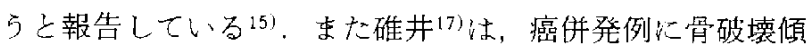
向が著明である上し，X線所見で骨破壞がみられたもの は19例中 5 例であり，そのうち癌併発例は３例で全例に骨 破壊が名られたとしている。さらに Marcial-Rojas ら ${ }^{101}$ は, 再発を繰り返し骨破壊がみられる症例に十分な病理組 織学的検索を行兄ば，关の大部分に癌を見い出せると主張 している。しかし，骨破壊が癌によるものか乳頭腫に上る ものかを明らかにした報告はない，本例も癌合併例であ り，眼窝上内側壁，鼻中隔，前頭洞天蓋に著明な骨破懐を 伴っているが，癌を見い出せたのは鼻腔腫瘍のごく・部で あり，我々は骨破壊の本体的乳頭腫自体以あるむの上考克 ている、また， Mainzer ら 少性本例のごとく前頭洞の mucocele 梾桩大をきたした症例を報告しこれて乳頭腫による 骨破壊の特徵としているが，本例においては長期にわたり 存在し増殖した乳頭腫により，また10数回の鼻茸切除術の ため前頭洞開口部に閉塞を生し， mucocele pyocele 竍したと考えたい，さらに inverted papillomaによる骨破 壊が加わり，前頭洞天蓋を破買したと思われる。

再発率は11〜70\%とされ，報告者に上りその追跡期間が まちまちで開きがみられるが，いずれの報告も高頻度に再 発することを指摘している ${ }^{13,17)}$. 本例东最近 20 年間に10数 回の鼻荤切除術を受计大既往を有し，著明な再発傾向を䂏 わせる。碓井 ${ }^{17}$ は再発傾向を左右する因子として上皮細胞 の異型性の程度, 原発部位, 進展範团などを挙げ，本例の ごとく腫瘍が前頭洞心まで波及し，局所清掃の困難な症例 ほど再発率が高いことを指摘している。

癌化については，1893年 Kiesselbach ${ }^{7}$ の報告を初めとし て多くの報告がみられる、癌化あるい嵒合併率注2 $20 \%$ とされ $13,16,17$ ，再発率同様報告者により開きがみられ るが，癌化の基準もまち束ちで，標本圭全割し十分な病理

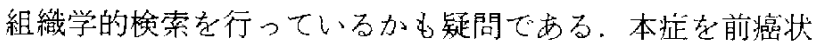

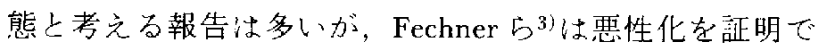

きる症例もなく初めから癌が－部飞共存している可能性を 指摘している．Marcial-Rojasら10が指摘したよ5に，十 分な病理組織学的娭索を全例に行兄ば，癌共存例めるいは 癌化を証明できる可能性は岛いと考えられる。

本例の進展形式はきれめて特異であり，興味深い，本腫 瘍はその激しい破壊性のため注日されているが， Mainzer や9は頭蓋内進展は事れであり，彼らの経験例 2 例を含め 5 例の報告があるにすぎない上している。 Mainzer 以徭, inverted papilloma の頭蓋内進展に関して は1981年徳田らの報告16)をみるのみであり，現在まで6例 にすぎない，頭蓋内進展形式はすべて骨破壊による頭蓋底 部への侵入であり，白験例のごとく明らかに硬膜をも貝い て脳内に侵入した症例は例学多ない，硬膜は一般に强勒な 組織であり，悪性腫㻛ですら硬膜を貫いて脳内汇侵入する

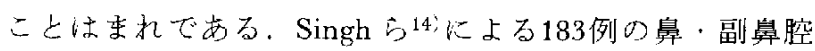
悪性腫瘍の検討では，頭蓋内進展を確認できたもの41例 $(22.4 \%)$ ，硬膜への浸潤を認めたもの7例 $(3.8 \%)$ ，前頭

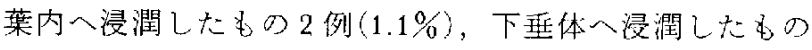
4 例 $(2.2 \%)$ で, transdural intracerebral invasion

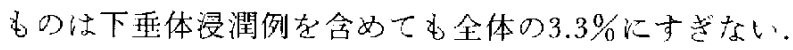
この上らに硬膜余非常に強勒な組織であるが，Paparella ら11) は慢性炎症によって硬膜破䋎をきたす病態を指摘して いる，本例ては陳归性脳膿瘍を合併しておう，これは慢性 炎症が強く関与したことを示唆する所見と考えられる。我 々は，本例の脳内侵入機序につき慢性炎症の関与が大きい と考え，以下のごとく推察した。すな拈ち，前頭洞内に長 期沈わたり存在し增殖した inverted papillomaによる前頭 洞開口部の閉塞のため，洞内に炎泟性分泌物が斯留し，洞 内珐上昇上之るに骨の下迫破壊を生し，さらにinverted papillomaによる骨破盽が加わって炎症が硬膜へ波及し， 慢性炎症による硬膜の脆弱化と inverted papilloma の浸潤 により硬膜が破綻して, inverted papilloma 㧍よび鼻内細 菌の細内侵入をきたしたと考觉た。

このよ5に, 鼻・副鼻㴈乳頭腫は, 骨破壊, 再発, 癌化 とともに, 本例のごとく慢性炎症の関与汇上り種々の病態 を呈する可能性も饬り，十分注意寺べき腫瘍であると思わ れた。

\section{$N$ 結 語}

良性腫瘍でありながら前頭洞天蓋を破壊し，硬膜をも貫 いて脳内侵入をきたし，脳膿瘍を伴った鼻・副鼻腔乳頭腫 の 1 例を報告し，その特異な病態および脳内侵入機序につ 考察を加克九。

本論文の要旨の一部は, 第19回日本脳神経外科学会関東地方会 
(1985年9月, 東京)に执いて発表した。

\section{文献}

1) Bill roth T: Uber dem Bau des Schleimpolyp. Berlin, Reimer, 1855, $\mathrm{p} 11$, cited in 6)

2) Cummings $\mathrm{CW}$, Goodman ML: Inverted papillomas of the nose and paranasal sinuses. Arch Otolaryngol 92: 445-449, 1970

3) Fechner RE, Alford DO: Inverted papilloma and squamous cell carcinoma. Arch Otolaryngol 88: 507-512, 1968

4）服部康夫，中村兼一，村上忠也，渡辺充，児太䮚一郎， 中村 賢, 弓削庫太 : 鼻, 副鼻腔 papilloma の超政形態学的観 察。日耳鼻会報 83:293-302, 1980

5) Hopman CM: Die papillaren Geschwulste der Nasenschleimhaut. Virchow Arch Path Anal 93: 213-258, 1883

6) Hyams VJ: Papillomas of the nasal cavity and paranasal sinuses. A clinicopathologic study of 315 cases. Ann Otol Rhinol Laryngol 80: 192-206, 1971

7) Kiesselbach: Ein Fall von Epithelioma papillare an der mittleren Nasenmuschel. Virchow Arch Path Anat 132: 371-376, 1893

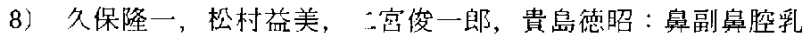

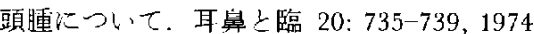

9) Mainzer F, Stargardter FL, Connolly ES, Eyster EF: Inverting papilloma of the nose and paranasal sinuses. Radiology 92: 964968, 1969

10) Marcial-Rojas RA, De Leon E: Epithelial papilloma of nose and accessory sinuses. Arch Otolaryngol 77: 634-639, 1963
11) Paparella MM, Mcyerhoff WL, Oliviera CA: Mastoiditis and brain hernia (mastoiditis cerebri). Laryngoscope 88: 1097-1106, 1978

12) Ringertz N: Pathology of malignant tumors arising in the nasal and paranasal cavities and maxilla. Acta Otolaryngol (Stockholm) 27 [Suppl]: 31-42, 1938

13) Sellars SL, Rosen G: The inverted nasal papilloma. J Laryngol Otol 96: 1109-1112, 1982

14) Singh SP, Martinson FD: Nervous system involvement in malignant tumors of the nose and paranasal sinuses. Afr.J Med Med Sci 5: 109 113, 1976

15) Skolnik EM, Loewy A, Fricdman JE: Inverted papilloma of the nasal cavity. Arch Otolaryngol 84: 61-67, 1966

16）徳田政道，滕川光弘，芦田浩，藤井正道，大竹英夫，河 合清隆，竹山 勇：鼻，副鼻腔に発生した inverted papilloma の2 例. 臨放線 26: 299-302, 1981

17)碓井康子：鼻,副鼻腔乳頭腫淀19例の臨床病理学的検討. 日耳鼻会報 87：665-673，1984

18) Ward N: Follicular tumor involving the nasal bones, nasal processes of superior maxillary bone, and the septum of the nose; removal; death from pneumonia; autopsy. Lancet 2: 480-482, 1854 , cited in 6 )

〔別刷請求先： $\mathbf{T} 160$ 東京都新宿区信濃町35，慶應義塾大学脳神 经外科, 内田耕一j 